\title{
RENAL MECHANISMS FOR THE EXCRETION OF INORGANIC SULFATE IN MAN *
}

\author{
By E. LOVELL BECKER, $†$ HENRY O. HEINEMANN, $\ddagger$ KIETSU IGARASHI,§ \\ JURG E. HODLER \| AND HERBERT GERSHBERG
}

\author{
(From the Department of Physiology, New York University School of Medicine, New York, \\ N. Y., and the Department of Medicine, Medical College of Virginia, \\ Richmond, $V a$.)
}

(Submitted for publication June 9, 1960; accepted August 18, 1960)

The sulfur contained in plasma is derived from sulfalipids, sulfatides, amino acids, and glycoproteins as well as from ionizable inorganic sulfate. The plasma concentration of inorganic sulfate is partially determined by the kidneys, since the ion is freely filterable at the glomerulus $(1,2)$ and reabsorbed by the renal tubules. In dogs (3) the excretory processes have been fairly well defined and the tubular reabsorptive mechanism has been shown to be characterized by a maximal transfer rate $\left(\mathrm{Tm}_{\mathrm{SO}_{4}}\right)$. The present study was undertaken to ascertain if similar mechanisms are operating in man. To elucidate this problem, the filtered load, tubular reabsorption, and urinary excretion of inorganic sulfate were measured prior to and during the infusion of sodium sulfate solution. Further, the readily exchangeable sulfate mass was determined using isotope dilution techniques. The results of this study show that the tubular reabsorption of inorganic sulfate in man is limited by a maximal transfer rate ( $\mathrm{Tm}$ ).

\section{MATERIALS AND METHODS}

Subjects. The subjects were convalescent patients without apparent cardiovascular, renal, or metabolic disorders, and healthy young adult volunteers. All subjects had been on an ordinary diet and were fasted 12 hours prior to the study.

Plan of study. Control blood and urine samples were used to determine the fasting plasma inorganic sulfate

* Supported in part by grants from the Virginia Heart Association and the United States Public Health Service (A-2325), Bethesda, Md.

$\dagger$ Present address: Department of Medicine, The New York Hospital-Cornell Medical Center, New York, N. Y.

$¥$ Present address: Department of Medicine, Columbia

University, College of Physicians and Surgeons, New York, N. Y.

§ Present address: Sendai National Hospital, Sendai, Japan.

|| Present address : Medizinische Klinik der Universität, Bern, Switzerland. concentration and the inulinoid blank in urine and plasma. To measure the glomerular filtration rate (GFR) a priming dose of inulin, administered to raise the blood level to approximately $0.25 \mathrm{mg}$ per $\mathrm{ml}$, was followed by a sustaining infusion containing inulin in saline, delivered by a Bowman constant infusion pump at a rate of $1.0 \mathrm{ml}$ per minute.

After an appropriate equilibration time, at least two urine collection periods were obtained for measurement of control glomerular filtration and sulfate excretion. Five per cent sodium sulfate ${ }^{1}$ was subsequently administered by a second constant infusion pump to insure an independent rate of infusion of 2 to $10 \mathrm{ml}$ per minute. Throughout each study, which lasted for about 4 hours, blood samples were obtained and urine collections were made at intervals of 30 to 40 minutes. Complete urine collections were obtained by urethral catheterization and bladder washout with $20 \mathrm{ml}$ of sterile distilled water followed by an equal volume of air.

Analytical methods. Inulin was determined by Schreiner's (4) modification of the method of Roe, and inorganic sulfate was analyzed by the method of Power and Wakefield (5).

Determination of the exchangeable sulfate mass. The readily available inorganic sulfate mass was calculated as the product of the fasting plasma inorganic concentration $\left(\mathrm{P}_{\mathrm{SO}_{4}}\right)$ and the simultaneously measured volume of distribution of radiosulfate $\left(\mathrm{V}_{\mathrm{s}^{35} \mathrm{O}_{4}}\right)$. The volume of distribution of radiosulfate was derived by dividing the total administered radioactivity by the plasma radioactivity at the time of injection (6). This latter value was obtained by extrapolating the exponential disappearance curve of the injected radiosulfate to zero time. No correction was made for urinary loss of radiosulfate during the equilibration time. According to Ryan, Pascal, Inoye and Bernstein (7), as much as 7.2 per cent of the administered dose is lost during equilibration. Therefore, the plasma concentration of radiosulfate obtained in this study is too high and the calculated volume of distribution is smaller than the extracellular fluid. However, the data obtained suffice for the needs of this study. The dried samples of plasma and urine, corrected for selfabsorption, were counted with a windowless gas-flow counter.

1 Sodium sulfate for intravenous administration was kindly supplied by Abbott Laboratories of North Chicago, Ill. 


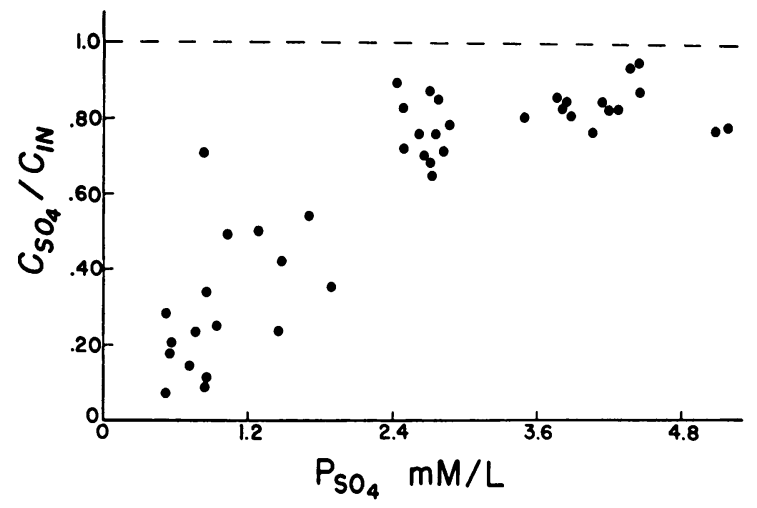

Fig. 1. The plasma sulfate concentration plotted against THE ClEARANCE Ratios of SUlfate AND INULIN.

Calculations. The tubular reabsorption of inorganic sulfate $\left(\mathrm{T}_{\mathrm{sO}_{4}}\right)$ was calculated as :

$$
\mathrm{T}_{\mathrm{SO}_{4}}=\left[\left(\mathrm{P}_{\mathrm{SO}_{4}}\right)(\mathrm{GFR})\right]-\left(\mathrm{U}_{\mathrm{SO}_{4} \mathrm{~V}}\right)
$$

where $\mathrm{P}_{\mathrm{So}_{4}}$ and $\mathrm{U}_{\mathrm{SO}_{4}}$ represent the plasma and urine concentrations of inorganic sulfate in micromoles per milliliter; GFR, glomerular filtration rate in milliliters per minute; and $\mathrm{V}$, the urine flow in milliliters per minute. The maximal tubular reabsorption of sulfate $\left(\mathrm{Tm}_{\mathrm{SO}_{4}}\right)$ was calculated by averaging the three highest values for tubular reabsorption during elevated plasma inorganic sulfate concentrations. This calculation was not corrected for equilibration of sulfate across a semipermeable membrane. Swan, Feinstein and Madisso (2) reported an equilibrium constant of 0.95 for man. If this factor had been applied, the load and $T \mathrm{~m}$ would have been slightly smaller.

\section{RESULTS}

Fasting plasma sulfate concentration. The fasting plasma sulfate concentration in millimoles of inorganic sulfate per liter of plasma, determined in 31 patients, varied between 0.2 and 1.1 mmoles per $\mathrm{L}$ (mean $0.6 \pm 0.2$ mmole per $\mathrm{L}$ ). No relationship was noted between the plasma sulfate concentration and age, sex, body weight, or readily exchangeable sulfate mass.

Fasting sulfate clearance. The fasting sulfate clearance $\left(\mathrm{U}_{\mathrm{SO}_{4}} \mathrm{~V} / \mathrm{P}_{\mathrm{SO}_{4}}\right)$ in 12 subjects ranged from 7.1 to $61.3 \mathrm{ml}$ per minute. In the fasting

TABLE I

Data obtained in three studies of a representative subject

\begin{tabular}{|c|c|c|c|c|c|c|c|}
\hline \multirow[b]{2}{*}{ GFR } & \multirow{2}{*}{$\begin{array}{l}\text { Plasma } \\
\text { sulfate }\end{array}$} & \multicolumn{3}{|c|}{ Sulfate } & \multirow{2}{*}{$\times\left(\mathrm{PsO}_{4}\right) / \mathrm{T}$} & \multirow[b]{2}{*}{$(\mathrm{T} / \mathrm{GFR}) 100$} & \multirow[b]{2}{*}{$\mathrm{T} / \mathrm{BW}$} \\
\hline & & Filtered & Excreted & Reabsorbed & & & \\
\hline $\begin{array}{l}m l / m i n \\
\text { No. } 1\end{array}$ & mmoles/L & & $\mu m o l e s / \min$ & & & $\begin{array}{c}\text { mmoles/ } \\
\min / 100 \\
m l G F^{*}\end{array}$ & 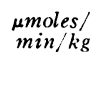 \\
\hline $\begin{array}{l}98.0 \\
98.0\end{array}$ & $\begin{array}{l}0.55 \\
0.55\end{array}$ & $\begin{array}{l}54.0 \\
54.0\end{array}$ & $\begin{array}{l}5.7 \\
5.8\end{array}$ & $\begin{array}{l}48.3 \\
48.2\end{array}$ & $\begin{array}{l}1.1 \\
1.1\end{array}$ & $\begin{array}{l}49.3 \\
49.3\end{array}$ & $\begin{array}{l}0.8 \\
0.8\end{array}$ \\
\hline \multicolumn{8}{|c|}{ Sulfate infusion } \\
\hline $\begin{array}{r}98.0 \\
114.0 \\
114.5\end{array}$ & $\begin{array}{l}1.43 \\
1.52 \\
1.95\end{array}$ & $\begin{array}{l}140.0 \\
173.0 \\
223.0\end{array}$ & $\begin{array}{r}3.22 \\
73.0 \\
130.0\end{array}$ & $\begin{array}{r}107.8 \\
100.0 \\
93.0\end{array}$ & $\begin{array}{l}1.3 \\
1.7 \\
2.4\end{array}$ & $\begin{array}{r}110.3 \\
88.0 \\
81.3\end{array}$ & $\begin{array}{l}1.8 \\
1.7 \\
1.6\end{array}$ \\
\hline \multicolumn{8}{|c|}{ No. 2 control } \\
\hline $\begin{array}{l}99.1 \\
81.7\end{array}$ & $\begin{array}{l}0.61 \\
0.52\end{array}$ & $\begin{array}{l}60.5 \\
42.5\end{array}$ & $\begin{array}{l}2.9 \\
2.0\end{array}$ & $\begin{array}{l}57.6 \\
40.5\end{array}$ & $\begin{array}{l}1.1 \\
1.1\end{array}$ & $\begin{array}{l}58.0 \\
49.5\end{array}$ & $\begin{array}{l}1.0 \\
0.7\end{array}$ \\
\hline \multicolumn{8}{|c|}{ Sulfate infusion } \\
\hline $\begin{array}{r}86.9 \\
105.8 \\
101.9 \\
89.4\end{array}$ & $\begin{array}{l}1.08 \\
1.21 \\
1.30 \\
1.70\end{array}$ & $\begin{array}{r}93.8 \\
128.0 \\
132.5 \\
152.0\end{array}$ & $\begin{array}{l}39.8 \\
58.2 \\
80.6 \\
95.0\end{array}$ & $\begin{array}{l}54.0 \\
69.8 \\
51.9 \\
57.0\end{array}$ & $\begin{array}{l}1.7 \\
1.8 \\
2.6 \\
2.7\end{array}$ & $\begin{array}{l}62.2 \\
66.0 \\
51.0 \\
63.8\end{array}$ & $\begin{array}{l}0.9 \\
1.2 \\
0.9 \\
1.0\end{array}$ \\
\hline \multicolumn{8}{|c|}{ No. 3 control } \\
\hline $\begin{array}{l}83.4 \\
83.4\end{array}$ & $\begin{array}{l}0.39 \\
0.39\end{array}$ & $\begin{array}{l}32.5 \\
32.5\end{array}$ & $\begin{array}{l}4.7 \\
5.8\end{array}$ & $\begin{array}{l}27.8 \\
26.7\end{array}$ & $\begin{array}{l}1.2 \\
1.2\end{array}$ & $\begin{array}{l}33.3 \\
32.0\end{array}$ & $\begin{array}{l}0.5 \\
0.5\end{array}$ \\
\hline \multicolumn{8}{|c|}{ Sulfate infusion } \\
\hline $\begin{array}{l}80.4 \\
77.5 \\
87.3\end{array}$ & $\begin{array}{l}0.60 \\
0.84 \\
1.23\end{array}$ & $\begin{array}{r}48.2 \\
65.1 \\
107.4\end{array}$ & $\begin{array}{r}7.2 \\
32.1 \\
65.2\end{array}$ & $\begin{array}{l}41.0 \\
33.0 \\
42.2\end{array}$ & $\begin{array}{l}1.2 \\
2.0 \\
2.6\end{array}$ & $\begin{array}{l}51.0 \\
42.7 \\
48.5\end{array}$ & $\begin{array}{l}0.7 \\
0.6 \\
0.7\end{array}$ \\
\hline
\end{tabular}

* Micromoles per minute per $100 \mathrm{ml}$ of glomerular filtrate (GF). 
TABLE II

Average data of all subjects

\begin{tabular}{|c|c|c|c|c|c|c|c|c|}
\hline Patient & BW & GFR & $\begin{array}{c}\mathrm{T} \\
\text { (control) }\end{array}$ & $\mathrm{Tm}$ & 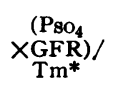 & $\mathrm{T} / \mathrm{Tm}$ & $(\underset{\times 100}{(\mathrm{Tm} / \mathrm{GFR})}$ & $\mathrm{Tm} / \mathrm{BW}$ \\
\hline & $\mathrm{kg}$ & $m l / m i n$ & $\underset{\min }{\mu \text { moles/ }}$ & $\underset{\text { min }}{\text { moles/ }}$ & & $\%$ & $\begin{array}{c}\text { mmoles/ } / \\
\min / 100 \\
m l G F \dagger\end{array}$ & $\underset{\mathrm{min} / \mathrm{kg}}{\mu \mathrm{moles} /}$ \\
\hline $\begin{array}{r}\text { CA no. } 1 \\
\text { no. } 2\end{array}$ & $\begin{array}{l}62.2 \\
62.2\end{array}$ & $\begin{array}{r}88 \\
109\end{array}$ & $\begin{array}{l}47 \\
65\end{array}$ & $\begin{array}{l}81 \\
84\end{array}$ & $\begin{array}{l}2.3 \\
3.6\end{array}$ & $\begin{array}{l}58.0 \\
77.4\end{array}$ & $\begin{array}{l}92.0 \\
77.1\end{array}$ & $\begin{array}{l}1.3 \\
1.4\end{array}$ \\
\hline $\begin{array}{r}\text { JO no. } 1 \\
\text { no. } 2\end{array}$ & $\begin{array}{l}59.1 \\
59.1\end{array}$ & $\begin{array}{l}87 \\
87\end{array}$ & $\begin{array}{r}98 \\
124\end{array}$ & $\begin{array}{l}189 \\
143\end{array}$ & $\begin{array}{l}2.4 \\
2.1\end{array}$ & $\begin{array}{l}51.9 \\
86.7\end{array}$ & $\begin{array}{l}217.2 \\
164.3\end{array}$ & $\begin{array}{l}3.2 \\
2.4\end{array}$ \\
\hline $\begin{array}{r}\text { NO no. } 1 \\
\text { no. } 2\end{array}$ & $\begin{array}{l}70.9 \\
70.9\end{array}$ & $\begin{array}{l}125 \\
156\end{array}$ & $\begin{array}{l}56 \\
61\end{array}$ & $\begin{array}{l}149 \\
111\end{array}$ & $\begin{array}{l}2.4 \\
4.7\end{array}$ & $\begin{array}{l}37.6 \\
55.0\end{array}$ & $\begin{array}{r}119.2 \\
71.2\end{array}$ & $\begin{array}{l}2.1 \\
1.6\end{array}$ \\
\hline $\begin{array}{r}\text { AD no. } 1 \\
\text { no. } 2\end{array}$ & $\begin{array}{l}65.5 \\
65.5\end{array}$ & $\begin{array}{l}130 \\
147\end{array}$ & $\begin{array}{r}108 \\
71\end{array}$ & $\begin{array}{l}150 \\
188\end{array}$ & $\begin{array}{l}2.3 \\
6.8\end{array}$ & $\begin{array}{l}72.0 \\
37.8\end{array}$ & $\begin{array}{l}115.4 \\
127.8\end{array}$ & $\begin{array}{l}2.3 \\
2.9\end{array}$ \\
\hline WE no. 1 & $\begin{array}{l}74.5 \\
74.5\end{array}$ & $\begin{array}{l}128 \\
118\end{array}$ & $\begin{array}{l}81 \\
75\end{array}$ & $\begin{array}{l}154 \\
168\end{array}$ & $\begin{array}{l}3.5 \\
3.8\end{array}$ & $\begin{array}{l}52.6 \\
44.6\end{array}$ & $\begin{array}{l}120.3 \\
142.4\end{array}$ & $\begin{array}{l}2.1 \\
2.3\end{array}$ \\
\hline $\mathrm{HE}$ & 65.5 & 89 & 34 & 36 & 2.2 & 94.4 & 40.4 & 0.6 \\
\hline RO & 59.0 & 100 & 33 & 47 & 4.9 & 70.2 & 47.0 & 0.8 \\
\hline PA & 63.6 & 125 & 66 & 156 & 1.7 & 42.3 & 124.8 & 2.5 \\
\hline MI & 62.7 & 112 & 47 & 75 & 3.2 & 62.7 & 66.9 & 1.2 \\
\hline DJ & 60.9 & 98 & 32 & 47 & 4.8 & 68.1 & 47.9 & 0.8 \\
\hline GA & 63.6 & 88 & 15 & 50 & 5.0 & 30.0 & 56.8 & 0.8 \\
\hline $\mathrm{CL}$ & 81.8 & 98 & 47 & 53 & 4.8 & 88.6 & 54.1 & 0.7 \\
\hline $\mathrm{EF}$ & 69.8 & 144 & 77 & 166 & 3.1 & 46.4 & 115.3 & 2.4 \\
\hline ST & 73.2 & 175 & 91 & 172 & 3.6 & 52.9 & 98.3 & 2.4 \\
\hline RI & 43.2 & 84 & 17 & 34 & 5.9 & 50.0 & 40.5 & 0.8 \\
\hline
\end{tabular}

* Highest load/Tm ratio; $\mathrm{Tm}=$ average of 3 periods with elevated sulfate load.

$\dagger$ Micromoles per minute per $100 \mathrm{ml}$ of glomerular filtrate (GF).

state tubular reabsorption of inorganic sulfate is close to maximal. Therefore, as the filtering load $\left[(\mathrm{GFR})\left(\mathrm{P}_{\mathrm{SO}_{4}}\right)\right]$ is increased, the clearance of sulfate also increases, approaching GFR, less the amount of sulfate reabsorbed by the tubules (Figure 1).

Tubular reabsorption of inorganic sulfate. In 23 studies on 16 subjects, tubular reabsorption of inorganic sulfate was determined before and during the administration of sodium sulfate. In all instances a maximal rate of sulfate reabsorption $\left(\mathrm{Tm}_{\mathrm{SO}_{4}}\right)$ was reached, and this was not increased by further elevation of the plasma sulfate concentration. The data obtained in three studies of a representative patient are shown in Table $I$. There was no reproducibility of fasting inorganic sulfate concentration on successive weekly studies. Variations are not due to changes in filtration rate, since this was remarkably constant. The load/T ratios in this patient ranged from control level of 1.05 to a high of 2.67 during sulfate infusion, well above that considered necessary to saturate the transfer mechanism. At these load/T ratios, no evidence of the self-depression phenomenon was noted.

Data for all other patients are summarized in Table II. Tubular reabsorption of inorganic sulfate varied markedly among individual patients and in repeated determinations in the same subject. The mean $\mathrm{Tm}_{\mathrm{SO}_{4}}$ was 113 mmoles per minute $(\mathrm{SD} \pm 55)$ and the coefficient of variation was

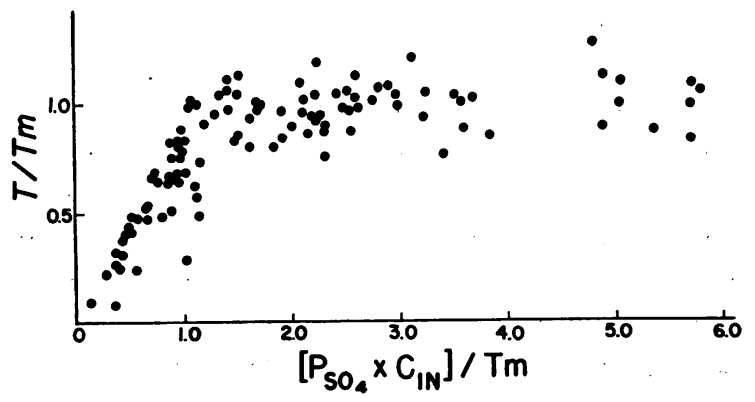

Fig. 2. Inorganic sulfate T/TM Plotted against the SULFATE LOAD/TM RATIOS. 
49 per cent. If the $\mathrm{Tm}_{\mathrm{SO}_{4}}$ is related to $100 \mathrm{ml}$ of glomerular filtrate, the mean was 97 mmoles per minute $(S D \pm 45)$ with a coefficient of variation of 47 per cent. Since there is no reproducibility and since the variation within each study is too great to permit comparison of the $\mathrm{Tm}_{\mathrm{SO}_{4}}$ among individuals, both the $\mathrm{T}_{\mathrm{SO}_{4}}$ and the filtered load $\left(\mathrm{P}_{\mathrm{SO}_{4}} \times \mathrm{GFR}\right)$ were factored by the maximal tubular transfer rate $\left(\mathrm{Tm}_{\mathrm{SO}_{4}}\right)$. These values, for all subjects, are plotted in Figure 2. Accepting the existence of a $\mathrm{Tm}$, this figure illustrates that the $\mathrm{T} / \mathrm{Tm}$ ratio approaches 1.0 as the load/Tm is raised above 1.0 , thereafter remaining constant to $\mathrm{load} / \mathrm{Tm}$ ratios of 5.0 .

\section{DISCUSSION}

The observed fasting plasma inorganic sulfate concentration of 0.6 mmole per $\mathrm{L}$ (equivalent to $1.9 \mathrm{mg}$ per $100 \mathrm{ml}$ sulfur, or $1.2 \mathrm{mEq}$ per L sulfate) is in agreement with values summarized by Hayman in 1932 (8) and later confirmed by others $(5,7,9-11)$. The plasma inorganic sulfate level is determined by many variables, such as protein catabolism, absorption from the gastrointestinal tract, and glomerular-tubular balance. As far as we know, the only variable that can be directly controlled is the dietary protein. The values obtained in this study represent an unselected sampling. since no attempt was made to regulate the diet.

With increasing loads, the sulfate clearance will approach glomerular filtration asymptotically because tubular reabsorption of sulfate is rapidly exceeded, and therefore the amount of filtered sulfate becomes relatively much greater than the amount of sulfate reabsorbed by the tubules.

The results of this study show that reabsorption of inorganic sulfate by the renal tubules is limited by a maximal rate $\left(\mathrm{Tm}_{\mathrm{SO}_{4}}\right)$. The variability of this $\mathrm{Tm}$ among individuals and in repeated observations in the same individual remains unexplained. This variability persists, if $\mathrm{Tm}$ is expressed per $100 \mathrm{ml}$ of glomerular filtrate, indicating that $\mathrm{Tm}_{\mathrm{SO}_{4}}$ is not comparable between individuals. Further, tubular reabsorption of inorganic sulfate is in man not dependent on GFR, although in the dog, $\mathrm{Tm}_{\mathrm{SO}_{4}}$ varies directly with the filtration rate (12). In determination of $\mathrm{Tm}_{\mathrm{SO}_{4}}$, it cannot be excluded that there is dif- fusion of sulfate from peritubular fluid to tubular urine as shown in the $\log$ after a single injection of radiosulfate $\left(\mathrm{S}^{35} \mathrm{O}_{4}\right)$ into the renal artery (13). To explore mechanisms which might conceivably be interdependent and affect the tubular reabsorption of sulfate, the readily available sulfate mass was related to the $\mathrm{Tm}_{\mathrm{SO}_{4}}$ but no correlation was noted.

Since sulfate is apparently actively reabsorbed in the kidney by a transfer mechanism showing limited capacity, it should follow the principle of an enzyme catalyzed reaction with a maximal reaction rate ( $\mathrm{Tm}$ ). Shannon in 1939 postulated (14) the general processes for the excretion of substances characterized by a Tm. Thompson and Hiatt (15) applied this concept to inorganic phosphate. The hypothesis could similarly be utilized for inorganic sulfate reabsorption.

Cohen. Berglund and Lotspeich (16) have reported that acetoacetate, phosphate, and sulfate share a common reaction with glucose during tubular reabsorption. They further demonstrated that glucose was preferentially reabsorbed, a reaction selectively inhibited by phlorizin, accelerating the reabsorption of acetoacetate, phosphate and sulfate.

Berglund and Lotspeich $(12,17)$ found in dogs that $l$-alanine, glycine, $l$-arginine and sodium chloride depress $\mathrm{Tm}_{\mathrm{SO}_{4}}$, conceivably because of specific inhibition of an enzyme, or because of competition for a carrier system. Evidence in favor of a carrier system was adduced by Berglund, Helander and Howe (18), who demonstrated in the dog mutual competitive inhibition between sulfate and thiosulfate reabsorption.

Gershberg, Hodler and Gasch (19) reported that a synthetic low protein diet in dogs caused an increase in the plasma sulfate concentration, possibly a result of increased tubular reabsorption. A high protein diet or DCA had no effect on tubular reabsorption, while cortisone increased the maximal rate of sulfate reabsorption. Gershberg and Gasch (20) also noted an increase in $\mathrm{Tm}_{\mathrm{SO}_{4}}$ in three of four dogs given growth hormone. They suggested that some intermediate change in protein metabolism induced by the hormone may affect $\mathrm{Tm}_{\mathrm{SO}_{4}}$. No attempts were made in the present study to alter the reabsorption of sulfate in man. 


\section{SUMMARY}

1. Tubular reabsorption of inorganic sulfate in man is limited by a maximal rate $\left(\mathrm{Tm}_{\mathrm{SO}_{4}}\right)$.

2. This tubular transfer rate is not reproducible in any one individual and varies markedly between individuals.

3. The mechanism responsible for the lack of reproducibility remains unexplained.

\section{ACKNOWLEDGMENTS}

The authors wish to express their appreciation to Drs. H. W. Smith, W. D. Lotspeich and F. Berglund for their suggestions in the preparation of this manuscript.

\section{REFERENCES}

1. Goudsmit, A., Jr., Power, M. H., and Bollman, J. L. The excretion of sulfates by the dog. Amer. J. Physiol. 1939, 125, 506.

2. Swan, R. C., Feinstein, H. M., and Madisso, H. Distribution of sulfate ion across semi-permeable membranes. J. clin. Invest. 1956, 35, 607.

3. Lotspeich, W. D. Renal tubular reabsorption of inorganic sulfate in the normal dog. Amer. J. Physiol. $1947,151,311$.

4. Schreiner, G. E. Determination of inulin by means of resorcinol. Proc. Soc. exp. Biol. (N. Y.) 1950, 74, 117.

5. Power, M. H., and Wakefield, E. G. A volumetric benzidine method for the determination of inorganic and ethereal sulfate in serum. J. biol. Chem. 1938, 123, 665.

6. Walser, M., Seldin, D. W., and Grollman, A. An evaluation of radiosulfate for the determination of the volume of extracellular fluid in man and dogs. J. clin. Invest. 1953, 32, 299.

7. Ryan, R. J., Pascal, L. R., Inoye, T., and Bernstein, L. Experiences with radiosulfate in the estimation of physiologic extracellular water in healthy and abnormal man. J. clin. Invest. 1956, 35, 1119.

8. Hayman, J. M., Jr., The excretion of inorganic sulphates. J. clin. Invest. 1932, 11, 607.
9. Keith, N. M., Power, M. H. and Peterson, R. D. The renal excretion of sucrose, xylose, urea and inorganic sulphates in normal man: Comparison of simultaneous clearances. Amer. J. Physiol. 1934, 108, 221.

10. Bourdillon, J., and Lavietes, P. H. Observations on the fate of sodium sulfate injected intravenously in man. J. clin. Invest. 1936, 15, 301.

11. Bjering, T. and Øllgaard, E. Studies in sulphate clearance. Acta med. scand. 1939, 102, 55.

12. Berglund, F., and Lotspeich, W. D. Renal tubular reabsorption of inorganic sulfate in the $d o g$, as affected by glomerular filtration rate and sodium chloride. Amer. J. Physiol. 1956, 185, 533.

13. Becker, E. L., and Thompson, D. D. Radiosulfate excretion by the normal dog kidney. Fed. Proc. 1959, $18,9$.

14. Shannon, J. A. Renal tubular excretion. Physiol. Rev. 1939, 19, 63.

15. Thompson, D. D., and Hiatt, H. H. Renal reabsorption of phosphate in normal human subjects and in patients with parathyroid disease. J. clin. Invest. 1957, 36, 550.

16. Cohen, J. J., Berglund, F., and Lotspeich, W. D. Renal tubular reabsorption of acetoacetate, inorganic sulfate and inorganic phosphate in the dog as affected by glucose and phlorizin. Amer. J. Physiol. 1956, 184, 91.

17. Berglund, F., and Lotspeich, W. D. Effect of various amino acids on the renal tubular reabsorption of inorganic sulfate in the dog. Amer. J. Physiol. 1956, 185, 539.

18. Berglund, F., Helander, C. G., and Howe, R. B. Inorganic sulfate and thiosulfate: Transport and competition in renal tubules of the dog. Amer. J. Physiol. 1960, 198, 586.

19. Gershberg, H., Hodler, J., and Gasch, J. Effect of diet and hormones on plasma sulfate and $\mathrm{Tm}_{\mathrm{SO}_{4} \text {. }}$. Fed. Proc. 1954, 13, 53.

20. Gershberg, H., and Gasch, J. Effect of growth hormone on sulfate $\mathrm{Tm}$, urea clearance and fasting blood glucose. Proc. Soc. exp. Biol (N. Y.) 1956, 91, 46 . 